\title{
Communication \\ Climate-Friendly Ethics Prescribed by Top World Airlines: Empirical Evidence
}

\author{
Dmitry A. Ruban ${ }^{1,2, *(\mathbb{D}) \text { and Natalia N. Yashalova }}{ }^{3}$ \\ 1 K.G. Razumovsky Moscow State University of Technologies and Management (The First Cossack \\ University), Zemlyanoy Val Street 73, 109004 Moscow, Russia \\ 2 Department of Management, Higher School of Business, Southern Federal University, 23-ja Linija Street 43, \\ 344019 Rostov-on-Don, Russia \\ 3 Department of Economics and Management, Business School, Cherepovets State University, Sovetskiy \\ Avenue 10, Cherepovets, 162600 Vologda Region, Russia; natalij2005@mail.ru \\ * Correspondence: ruban-d@mail.ru
}

Received: 15 August 2020; Accepted: 17 October 2020; Published: 19 October 2020

check for updates

\begin{abstract}
The aviation industry contributes substantially to the global climate change, and, thus, airline companies need development of climate-friendly ethics. The content of the codes of conduct of 16 airline companies boasting either the greatest number of daily departures or the largest air fleet (or both) are analyzed. It is established that $25 \%$ of these companies prescribe climate-friendly behavior often focusing on emissions. Moreover, many other companies prescribe pro-environmental behavior. The situation seems to be promising, although improvements of the existing corporate ethical prescriptions are necessary. Despite its tentative character and certain limitations, this study permits putting the climate-friendly ethics of airlines on the international agenda. Practically, it is important to add climate-related notions to those codes of conduct where these do not exist and to use successful examples as ethical templates for the entire aviation industry.
\end{abstract}

Keywords: aviation; corporate documents; eco-ethics; emissions; strategic management

\section{Introduction}

Climate change is among the most important challenges of modern society, in regard to the anticipated global temperature rise, precipitation regime alteration, and natural hazard intensification [1-3]. The remaining skepticism [4] leads to inaction costing too much [5]. The significant human contribution to the ongoing climate change through greenhouse gas emissions is undisputable, and air transport, the growth of which is fueled by globalization and tourism, is among the most contributing industries [6-14]. Notably, this industry itself is affected by climate change $[15,16]$. Various technologies and policies (international, national, and corporate) can help to reduce the climate change impact of aviation, but it appears similarly important to stimulate climate-friendly business behavior in airline companies to change the very frame of thinking and to increase the level of awareness and responsibility in this industry.

Climate-friendly behavior encompasses actions made responsibly in regard to the human contribution to climate change (e.g., see various treatments of this idea in [17-21]). In the business sphere, this behavior is linked to corporate activity, work of owners, managers, and ordinary employees, and principles of partnership development. Evidently, climate-friendly behavior should be based on some norms that need to be well-formulated, properly fixed, and effectively communicated. If so, the shared corporate strategy based on intention and communication (the terminology after Steensen [22]) seems to be the most suitable approach. A code of conduct (code of business ethics, code of corporate ethics, etc.) seems to be corporate document of utmost importance that formulates, 
fixes, and communicates the company's prescriptions for climate-friendly behavior. Not being a panacea, these codes contribute to organizational changes, strategy implementation, and ethics improvement [23-27]. Although following the prescribed climate-friendly behavior is necessary to cultivate climate change responsibility in a given company, the very prescriptions should also be regarded as implementation of this responsibility because these prescriptions reflect company priorities and make a clear distinction between what is "legal" and what is not. Codes of conduct of airline companies can provide very important information about climate-friendly behavior prescribed in this industry.

The main objective of the present, essentially empirical study is to provide 'fresh' evidence of the climate change-ethical prescriptions by some top airline companies of the world. This analysis is very tentative and does not pretend to cover the issue comprehensively. However, it appears to be important at this stage to evaluate whether or not this issue exists and whether it is suitable to future investigations. One can expect that the significant contribution of air transport to climate change would make climate-friendly ethics very relevant to airline strategies, with establishment of the relevant norms in their codes of conduct. The present study aims at preliminary answering whether the companies are ready to incorporate special norms in their business. Being essentially a communication of tentative results, the present paper provides empirical evidence in favor of putting the problem on the international agenda.

\section{Materials and Methods}

Several studies have laid down the theoretical and methodological foundations for corporate ethics analyses of the aviation industry. Duppati et al. [28] stress the role of company behavior in their analysis of corporate governance in this industry. Paek and Chathoth [29] demonstrate that the ethics-related management (e.g., behavior prescriptions in strategic documents and practices of its control) in airline companies is more or less significant and coherent. Belyaeva [30], Cheng and Shen [31], and Hagmann et al. [32] show the interrelation between corporate and customers' ethical (also eco-ethical) practices and judgments. Burns and Cowlishaw [33] explain the importance of attention to statements on company web-pages to analyze their corporate understanding of the climate change issue.

Airline companies are ranked by different criteria, including indicators of their environmental performance, number of passengers and staff members, RPKs (revenue passenger kilometers), etc. The present study focuses on the climate change impact of the aviation industry, and, thus, it is important to consider criteria that are relevant to this impact. Two of them are the average number of daily departures and the number of aircraft. Evidently, the companies ranked higher by these criteria seem to be among the most contributing to the global climate change. The relevant rankings are available [34,35]. One of them considers 15 companies, and, thus, also 15 companies with the highest parameter value are considered from the other ranking. As some companies occur in both rankings, the total number of the considered companies is 21. Codes of conduct are publicly available for 16 of them, and these documents constitute the material for the present analysis (Table 1). The sample size is restricted, but this is not a significant limitation. On the one hand, the really top world airlines are considered (ethical norms in lesser companies may differ essentially, and, thus, the combined evidence may be confusing). On the other hand, this study is only tentative, and, thus, it does not require a huge sample size. Importantly, the considered companies represent different countries and different parts of the world, and, thus, the sample is rather representative. A third of the companies are headquartered in the USA (Table 1), but this reflects the industry concentration in this country. Nonetheless, the scarcity of information about the Chinese airlines is a limitation. To avoid any occasional violation of corporate interests, reputation, or image, all codes of conduct are treated anonymously, i.e., the outcomes of the present analysis are not associated with the companies' names. 
Table 1. The airline companies considered in the present study.

\begin{tabular}{|c|c|c|c|c|}
\hline Company & Daily Departures [34] & Number of Aircraft [35] & Country & Analyzed Document \\
\hline Aeroflot & 938 & 370 & Russia & Code of Corporate Ethics \\
\hline Air Canada & 1325 & $\mathrm{n} / \mathrm{a}$ & Canada & $\begin{array}{l}\text { Corporate Policy and } \\
\text { Guidelines on Business Conduct }\end{array}$ \\
\hline Air France-KLM & $\begin{array}{l}1010 \text { (Air France), } \\
675 \text { (KLM) }\end{array}$ & 542 & $\begin{array}{c}\text { France } \\
\text { (the Netherlands) }\end{array}$ & Code of Conduct (KLM) \\
\hline Alaska Airlines & 1119 & $\mathrm{n} / \mathrm{a}$ & USA & Code of Conduct and Ethics \\
\hline ANA & 1224 & $\mathrm{n} / \mathrm{a}$ & Japan & $\begin{array}{l}\text { Compliance and Ethics } \\
\text { Rules of Conduct }\end{array}$ \\
\hline Delta Air Lines & 4290 & 1069 & USA & $\begin{array}{l}\text { Code of Ethics and } \\
\text { Business Conduct }\end{array}$ \\
\hline IndiGo & 1665 & $\mathrm{n} / \mathrm{a}$ & India & $\begin{array}{l}\text { Code of Conduct for Directors } \\
\text { and Senior Management }\end{array}$ \\
\hline Lufthansa & 720 & 783 & Germany & Code of Conduct \\
\hline Ryanair & 2151 & 474 & Ireland & $\begin{array}{l}\text { Code of Business Conduct } \\
\text { and Ethics }\end{array}$ \\
\hline SkyWest Airlines & $\mathrm{n} / \mathrm{a}$ & 615 & USA & Code of Conduct \\
\hline Southwest Airlines & 3795 & 719 & USA & Code of Ethics \\
\hline Turkish Airlines & 1379 & 343 & Turkey & $\begin{array}{c}\text { Corporate Governance } \\
\text { Principles Compliance Report }\end{array}$ \\
\hline United Airlines & 4048 & 758 & USA & $\begin{array}{l}\text { Code of Ethics and } \\
\text { Business Conduct }\end{array}$ \\
\hline
\end{tabular}

Note: $\mathrm{n} / \mathrm{a}$-information not available in the considered source (other sources are not involved to avoid unnecessary data mix).

The content of each code of conduct is examined to find all phrases and word expressions linked to climate change, its particular aspects, and environmental issues in general. This is objective procedure because climate- and environment issues are either stated or not (these cannot be stated indirectly). The qualitative information is elementary, as the noted phrases and expressions available in the codes are chiefly very simple and short.

These phrases and word expressions are analyzed as follows. First, it is checked whether or not pro-environmental behavior (general environmental ethical norms) is prescribed in a given document (this is done via checking the presence or the absence of the relevant phrases and word expressions). Second, climate change considerations in the codes are classified into three categories. These may be direct (notions referring to climate change, greenhouse gases emissions, etc.) or indirect (presumably, some code writers may not make distinction between pro-environmental and climate-friendly behavior, and, thus, general environmental notions can be understood as also relevant to climate change, although indirectly). In some cases, neither climate-friendly, nor pro-environmental behavior is prescribed. Third, attention is paid to eco-ethical approaches, i.e., desirable actions of companies, workers, and managers prescribed in the codes. Specifying these approaches permits to understand what the company expects from itself and its workers. Fourth, it is valuable to differentiate between the codes paying significant attention to environmental and climate-related issues and those mentioning these issues superficially. For this purpose, the emphasis on these issues in each given code is evaluated with scoring, when the minimum value of 0 corresponds to the absence of emphasis and the maximum value of 3 corresponds to the very strong emphasis. The scores are relational, and they reflect how lengthy and detailed are phrases and word expressions in the codes. The above-mentioned analytical procedures are tentative. Nonetheless, they refer to the climate- and environment-related information available in the codes and characterized by simplicity. Moreover, they permit to characterize the state of prescriptions of the climate-change ethics by the analyzed airline companies, which are the leaders of the world aviation industry. 
The preference of chiefly qualitative analysis of codes to quantitative content-analysis techniques is not a limitation for two reasons. First, although only English versions of the codes of conduct are analyzed, some of them are written in the countries that are not English-speaking, and, thus, vocabulary, stylistic, and grammar peculiarities challenge the utility of automated, quantitative techniques. Second, environmental and climate-related issues can be described with very different words, expressions, and phrases (particularly, because code writers are experts in management and ethics, not necessarily in natural sciences), and, thus, word-by-word checking of the codes is the most (or even the only) powerful analytical principle.

\section{Results}

More than $80 \%$ the analyzed codes of conduct of the top world airlines bear certain prescriptions of pro-environmental behavior (Table 2). However, climate-related issues appear in only $25 \%$ of the documents, whereas the other codes can be related to the global climate change problem only indirectly, i.e., through the considerations of environmental issues. This means that the ethical norms of the airline companies are 'greened' significantly, but the attention to climate change is somewhat restricted. Generally, this implies that climate-friendly behavior is stimulated by the codes of conduct on an uncommon basis.

Table 2. Climate-friendly behavior recommended by the considered airline companies.

\begin{tabular}{|c|c|c|c|}
\hline Company * & $\begin{array}{l}\text { Pro-Environmental } \\
\text { Behavior }\end{array}$ & $\begin{array}{l}\text { Climate Change } \\
\text { Consideration }\end{array}$ & Eco-Ethical Approach \\
\hline A & Prescribed & Direct: emissions & $\begin{array}{l}\text { Following eco-laws and eco-norms, monitoring, } \\
\text { internal reporting, eco-training }\end{array}$ \\
\hline $\mathrm{B}$ & Prescribed & Indirect & $\begin{array}{l}\text { Following eco-laws and eco-norms, minimizing environmental } \\
\text { imprint, internal reporting }\end{array}$ \\
\hline $\mathrm{C}$ & Prescribed & Indirect & Following eco-laws and eco-norms, internal reporting \\
\hline $\mathrm{D}$ & Not prescribed & & Absent \\
\hline $\mathrm{E}$ & Prescribed & Indirect & Following eco-laws and eco-norms \\
\hline $\mathrm{F}$ & Not prescribed & & Absent \\
\hline G & Prescribed & $\begin{array}{l}\text { Direct: climatic } \\
\text { responsibility }\end{array}$ & Following eco-laws and eco-norms \\
\hline $\mathrm{H}$ & Prescribed & Direct: emissions & $\begin{array}{c}\text { Following eco-laws and eco-norms, resources conservation, } \\
\text { energy conservation, recycling, internal reporting, } \\
\text { personal alertness }\end{array}$ \\
\hline I & Prescribed & Indirect & $\begin{array}{c}\text { Natural resources preservation, participation in environmental } \\
\text { activities, eco-training, looking for opportunities to minimize } \\
\text { environmental; impact }\end{array}$ \\
\hline $\mathrm{J}$ & Prescribed & Indirect & $\begin{array}{l}\text { Integration of sustainable practices, recycling, } \\
\text { energy conservation, eco-training }\end{array}$ \\
\hline K & Prescribed & Direct: emissions & $\begin{array}{l}\text { Preventing unfavorable and damaging impacts on environment, } \\
\text { following eco-laws and eco-norms, reduce waste, emissions, } \\
\text { and toxic materials, respect the environmental rights of the locals, } \\
\text { efficient use of natural resources, recycling, eco-innovations, } \\
\text { attention to risky situations }\end{array}$ \\
\hline $\mathrm{L}$ & Prescribed & Indirect & $\begin{array}{l}\text { Reducing environmental effects on business activity, } \\
\text { efficient resource use, eco-technologies development and } \\
\text { implementation, following eco-laws and eco-norms, eco-training, } \\
\text { environmental management system }\end{array}$ \\
\hline M & Prescribed & Indirect & $\begin{array}{c}\text { Awareness of environmental impact, mitigation of environmental } \\
\text { impact balanced with business needs }\end{array}$ \\
\hline $\mathrm{N}$ & Not prescribed & & Absent \\
\hline $\mathrm{O}$ & Prescribed & Indirect & Care of environment, minimizing environmental impact \\
\hline $\mathrm{P}$ & Prescribed & Indirect & $\begin{array}{c}\text { Care of environment, improvement in energy efficiency, } \\
\text { improvement in environmental efficiency, following eco-laws and } \\
\text { eco-norms, environmental management system, } \\
\text { use of eco-technologies }\end{array}$ \\
\hline
\end{tabular}

Note: * company names are not disclosed to avoid occasional challenge of corporate interests. 
In the cases when the climate-related notions are found in the codes, these are chiefly treated in the context of emissions (Table 3), which generally reflects the true airline contribution to the global climate change. In one case, a notion deals with climatic responsibility. This treatment of the problem may be considered too general, or even vague, although it may also be judged advanced because climatic responsibility is something more than just attention to emissions. The analyzed codes of conduct offer broad spectrum of eco-ethical approaches (Table 2). Importantly, many codes prescribing climate-friendly behavior directly boast significant diversity of such approaches, some of which are specified in detail. This means strict adherence to these codes can lead to very accurate implementation of climate-friendly ethical norms. Interestingly, the airline companies with the codes focusing on the issue of climate change represent not only very different countries, but also different regions of the planet (but none of these companies is European).

Table 3. Excerpts from the codes of the airline companies focusing on the climate-friendly behavior.

\begin{tabular}{|c|c|c|}
\hline Company * & Excerpt from the Company Code & Comment \\
\hline A & $\begin{array}{c}\text { "We comply with laws that safeguard the environment } \\
\text { and promptly address any situation that results in the } \\
\text { unauthorized discharge or emission of pollutants into } \\
\text { the air, ground, or water." }\end{array}$ & $\begin{array}{l}\text { The company prescribes analysis (and, } \\
\text { thus, mitigation) of emissions. }\end{array}$ \\
\hline G & $\begin{array}{l}\text { "Our Incorporation carries on its domestic and } \\
\text { international activities by taking into account both its } \\
\text { climatic and environmental as well as } \\
\text { social responsibilities." }\end{array}$ & $\begin{array}{l}\text { The company states its climate } \\
\text { change responsibility. }\end{array}$ \\
\hline $\mathrm{H}$ & $\begin{array}{l}\text { "All employees should strive to conserve resources and } \\
\text { reduce waste and emissions through recycling and } \\
\text { other energy conservation measures. Employees have a } \\
\text { responsibility to promptly report to [company name } \\
\text { and its internal structures not to be disclosed] any } \\
\text { known or suspected violations of environmental laws } \\
\text { or any events that may result in a discharge or } \\
\text { emission of hazardous materials." }\end{array}$ & $\begin{array}{c}\text { The company requires from its workers } \\
\text { to reduce emissions and to report } \\
\text { situations leading to emissions. }\end{array}$ \\
\hline K & $\begin{array}{l}\text { "Reduce waste, emissions and use of toxic material, } \\
\text { according to the procedures defined internally." }\end{array}$ & $\begin{array}{l}\text { The company appeals to the } \\
\text { international agenda and prescribed } \\
\text { emission minimization. }\end{array}$ \\
\hline
\end{tabular}

Note: * company names are not disclosed to avoid occasional challenge of corporate interests.

The eco-ethical considerations in the codes of conduct of the top world airlines differs, and the emphasis ranges from absent (score 0 ) or weak (score 1) to strong (score 3) (Table 4). The frequency of the scores implies weak emphasis prevails, but strong emphasis is also not uncommon. As for the codes focusing on the climate-friendly behavior (the companies A, G, H, K-see Tables 2 and 3), all these (with the only exception) boast the codes of conduct with strong eco-ethical emphasis (score 3) (Table 4), if even the climate-related notions themselves are brief (Table 3). This means that the norms of the climate-friendly behavior are established by the companies that are really environmentally-"dedicated", i.e., the premises for successful implementation of the climate-related ethics are apparently high in these cases. 
Table 4. Attention to pro-environmental and climate-friendly behavior in the codes of conduct of the considered airline companies.

\begin{tabular}{|c|c|c|}
\hline Company * & Eco-Ethics and Climate Change-Ethics Emphases & Score $* *$ \\
\hline A & $\begin{array}{l}\text { Detailed explanation of the desirable pro-environmental behavior with } \\
\text { templates; emissions are considered very briefly }\end{array}$ & 3 \\
\hline $\mathrm{B}$ & Brief notions on pro-environmental actions & 1 \\
\hline $\mathrm{C}$ & Clear, but abridged explanation of the desirable pro-environmental behavior & 2 \\
\hline $\mathrm{D}$ & No & 0 \\
\hline $\mathrm{E}$ & Very general explanation of the desirable pro-environmental behavior & 1 \\
\hline $\mathrm{F}$ & No & 0 \\
\hline G & Brief notions on environmental and climatic responsibility & 1 \\
\hline $\mathrm{H}$ & $\begin{array}{l}\text { Brief, but detailed explanation of the desirable pro-environmental behavior; } \\
\text { employee responsibility for emissions }\end{array}$ & 3 \\
\hline I & Clear, but abridged explanation of the desirable pro-environmental behavior & 2 \\
\hline $\mathrm{J}$ & Brief notions on pro-environmental actions & 1 \\
\hline $\mathrm{K}$ & $\begin{array}{l}\text { Detailed explanation of the desirable pro-environmental behavior with listing } \\
\text { risky situations; emissions are considered very briefly }\end{array}$ & 3 \\
\hline $\mathrm{L}$ & Brief, but detailed explanation of the desirable pro-environmental behavior & 3 \\
\hline M & Very general explanation of the desirable pro-environmental behavior & 1 \\
\hline $\mathrm{N}$ & No & 0 \\
\hline $\mathrm{O}$ & Very general and too brief notions on pro-environmental actions & 1 \\
\hline $\mathrm{P}$ & Clear, but abridged explanation of the desirable pro-environmental behavior & 2 \\
\hline
\end{tabular}

Notes: * company names are not disclosed to avoid occasional challenge of corporate interests; ${ }^{* *}$ scores reflect how extensive (lengthy) and detailed are phrases and word expressions.

\section{Discussion and Conclusions}

The present analysis of the codes of conduct implies that the climate-friendly ethics is prescribed by only some of the top world airlines. An important question is whether the appearance of the climate-related phrases and word expressions in $25 \%$ of the codes should be deemed as a failure or success. On the one hand, the contribution of the aviation industry to the global climate change is really significant [6-14], and, thus, strict prescription of the climate-friendly behavior seems to be a must for all companies. On the other hand, the codes of conduct do not serve to reflect all business concerns and responsibilities (there are other corporate documents-e.g., sustainability strategies), and, thus, prescribing eco-ethics is voluntary. When this is done, a very high level of understanding of environmental and climate change responsibility of a given company can be supposed. Moreover, the majority of the companies prescribe pro-environmental ethics (Table 2) that is linked indirectly to the climate-friendly behavior: it would be difficult to suppose a truly environmentally-focused company ignoring emissions. Moreover, those $25 \%$ of the airlines with codes of conduct bearing the climate-related notions are able to lead the entire aviation industry and to facilitate posing correct ethical norms. Apparently, the top world airlines are aimed at implementation of the climate-friendly behavior, although this is not full implementation (the codes of conduct may be followed or not), but what can be called "starting implementation" via setting and promoting the rules clarifying what is desirable and permitted ("legal") and what is not. 
The results of the present study need to be compared to the outcomes of some previous research Burns and Cowlishaw [33] report that strategic communication of the climate change issues through the corporate web-pages of the UK airlines is very heterogeneous. Although the sample of the present study differs essentially, one can note the absence of such a heterogeneity: when the climate friendliness is addressed in the analyzed codes, it is chiefly related to emissions, diverse eco-ethical approaches, and strong environmental emphasis (Tables 2-4). The analyses of the mission statements of international airline companies undertaken first by Kemp and Dwyer [36] and later by Law and Breznik [37] imply that environmental (including climate-related) concerns occur in these statements relatively rarely. This contrasts to what is established in the codes of conduct (Tables 2 and 4). One can even go so far to hypothesize that eco-ethics is something more practical in the eyes of company managers, and, thus, it finds place in the codes in conduct rather than in some other corporate documents. However, different reflection of environmental and climate-related issues in the corporate documents may be also a sign of the heterogeneous communication revealed by Burns and Cowlishaw [33]. Anyway, it is worth considering that the antecedents of the pro-environmental and climate-friendly behavior may not be necessarily found in the other corporate documents, and this proposition is notable both conceptually and methodologically.

Although this study is empirical and it serves chiefly to document the current situation in the world aviation industry, the findings are enough for certain conceptualization. Particularly, this study raises the question of the quality and functions of corporate environmental communication through strategic documents. This question should be put on the current research agenda, as it refers to a very urgent and hotly-debated problem of the efficacy of corporate documents in environmental policy [38]. It seems to be possible to consider codes of conduct as an important channel of corporate environmental communication, as well as to state that the information in the codes may differ from what is said in the other strategic statements. On the one hand, this situation suggests that cavities in some documents can be recompensed by the other documents. On the other hand, several communication channels can function efficiently only when they provide coherent information; otherwise, a kind of information noise may appear (this is harmful to reputation of corporations, as well as to clarity of behavior norms to their workers). The highly-complex response of the audience to the climate-related information (e.g., [39]) indicates on potential danger of the noted noise. Another important issue is linked to the industry-scale climate-friendly actions. For instance, the idea of bio-aviation fuels is currently discussed [40-43]. If judged suitable, its implementation will require full understanding of the necessity of such an innovation. Codes of conduct form premise for this understanding within the aviation industry, but only when their prescriptions are coherent on the industry scale. So, an important theoretical and practical question is how climate-friendly ethics can shift from corporate to industry-scale initiatives. The role of the state in this shift can be significant, especially when ecology-related national projects are realized (the case of Russia [44,45]). Such major initiatives would include development and promotion of the most promising climate- and environment-related ethical norms among the entire industries.

Conclusively, the empirical evidence suggests that several top world airlines prescribe the climate-friendly ethics directly, and many companies prescribe pro-environmental behavior. The registered prescriptions are sensible and can facilitate successful implementation of eco-ethics in the aviation industry. The main limitation of this study is the sample size, and its increase in future investigations would require consideration of a non-linear dependence between company size and its ecological 'dedication'. Practically, this study has two principal implications. First, it indicates on the cavities in corporate ethical developments and stresses the necessity of the shift from the general environmental concerns to the climate change issue. Second, it implies the presence of several positive examples of the climate change treatment in the codes of conduct that can be used as templates by the other companies of the aviation industry. 
The present study realizes that the climate-friendly behavior prescribed by airlines is an existing issue that requires comprehensive investigations in the future. Particularly, the attention should be paid to successful practices of the relevant ethical prescriptions and their distribution across the entire aviation industry. Of crucial importance is the question of how eco-prescriptions are actually followed by the companies and their staff members, i.e., the pro-environmental and climate-friendly behavior really exists, or it remains at a start point when the rules are established, but not yet working. Future investigations should also aim at considering the larger number of airlines and their rankings by very different criteria, including RPKs.

Author Contributions: Conceptualization, D.A.R. and N.N.Y.; writing, D.A.R.; project administration, N.N.Y. All authors have read and agreed to the published version of the manuscript.

Funding: This research received no external funding.

Acknowledgments: The authors gratefully thank the editorial team and the reviewers for their support and precious recommendations.

Conflicts of Interest: The authors declare no conflict of interest. All considered codes of conduct are treated anonymously, i.e., these are not associated with the company names to avoid any challenge of corporate interests.

\section{References}

1. Edmonds, H.K.; Lovell, J.E.; Lovell, C.A.K. A new composite climate change vulnerability index. Ecol. Indic. 2020, 117, 106529. [CrossRef]

2. Houghton, J. Global Warming. The Complete Briefing; Cambridge University Press: Cambridge, UK, 2009.

3. Ramanathan, V.; Carmichael, G. Global and regional climate changes due to black carbon. Nat. Geosci. 2008, 1, 221-227. [CrossRef]

4. Milfont, T.L.; Abrahamse, W.; MacDonald, E.A. Scepticism of anthropogenic climate change: Additional evidence for the role of system-justifying ideologies. Personal. Individ. Differ. 2021, 168, 110237. [CrossRef]

5. Sanderson, B.M.; O'Neill, B.C. Assessing the costs of historical inaction on climate change. Sci. Rep. 2020, 10, 9173. [CrossRef] [PubMed]

6. Chapman, L. Transport and climate change: A review. J. Transp. Geogr. 2007, 15, 354-367. [CrossRef]

7. Debbage, K.G.; Debbage, N. Aviation carbon emissions, route choice and tourist destinations: Are non-stop routes a remedy? Ann. Tour. Res. 2019, 79, 102765. [CrossRef]

8. Gössling, S.; Humpe, A.; Bausch, T. Does 'flight shame' affect social norms? Changing perspectives on the desirability of air travel in Germany. J. Clean. Prod. 2020, 266, 122015.

9. Jordão, T.C. Analysis of fuel efficiency of largest European airlines in the context of climate change mitigation. Int. J. Glob. Energy Issues 2016, 39, 253-270. [CrossRef]

10. Lee, D.S.; Pitari, G.; Grewe, V.; Gierens, K.; Penner, J.E.; Petzold, A.; Prather, M.J.; Schumann, U.; Bais, A.; Berntsen, T.; et al. Transport impacts on atmosphere and climate: Aviation. Atmos. Environ. 2010, 44, 4678-4734. [CrossRef] [PubMed]

11. Macintosh, A.; Downie, C. Aviation and climate change: Can the airline industry continue to grow in a carbon-constrained economy? Australas. J. Environ. Manag. 2008, 15, 253-265. [CrossRef]

12. Peeters, P.; Higham, J.; Kutzner, D.; Cohen, S.; Gössling, S. Are technology myths stalling aviation climate policy? Transp. Res. Part D Transp. Environ. 2016, 44, 30-42. [CrossRef]

13. Ritchie, B.W.; Sie, L.; Gössling, S.; Dwyer, L. Effects of climate change policies on aviation carbon offsetting: A three-year panel study. J. Sustain. Tour. 2020, 28, 337-360. [CrossRef]

14. Sgouridis, S.; Bonnefoy, P.A.; Hansman, R.J. Air transportation in a carbon constrained world: Long-term dynamics of policies and strategies for mitigating the carbon footprint of commercial aviation. Transp. Res. Part A Policy Pract. 2011, 45, 1077-1091. [CrossRef]

15. Gratton, G.; Padhra, A.; Rapsomanikis, S.; Williams, P.D. The impacts of climate change on Greek airports. Clim. Chang. 2020, 160, 219-231. [CrossRef]

16. Ryley, T.; Baumeister, S.; Coulter, L. Climate change influences on aviation: A literature review. Transp. Policy 2020, 92, 55-64. [CrossRef]

17. Cologna, V.; Siegrist, M. The role of trust for climate change mitigation and adaptation behaviour: A meta-analysis. J. Environ. Psychol. 2020, 69, 101428. [CrossRef] 
18. Peters, G.P. Carbon footprints and embodied carbon at multiple scales. Curr. Opin. Environ. Sustain. 2010, 2, 245-250. [CrossRef]

19. Thaller, A.; Fleiß, E.; Brudermann, T. No glory without sacrifice-Drivers of climate (in)action in the general population. Environ. Sci. Policy 2020, 114, 7-13. [CrossRef]

20. Vainio, A.; Mäkiniemi, J.-P. How Are Moral Foundations Associated with Climate-Friendly Consumption? J. Agric. Environ. Ethics 2016, 29, 265-283. [CrossRef]

21. Yoon, J.I.; Kyle, G.T.; van Riper, C.J.; Sutton, S.G. Testing the Effects of Constraints on Climate Change-Friendly Behavior among Groups of Australian Residents. Coast. Manag. 2013, 41, 457-469. [CrossRef]

22. Steensen, E.F. Five types of organizational strategy. Scand. J. Manag. 2014, 30, 266-281. [CrossRef]

23. Bia, M.; Kalika, M. Adopting an ICT code of conduct: An empirical study of organizational factors. J. Enterp. Inf. Manag. 2007, 20, 432-446. [CrossRef]

24. Bird, Y.; Short, J.L.; Toffel, M.W. Coupling labor codes of conduct and supplier labor practices: The role of internal structural conditions. Organ. Sci. 2019, 30, 847-867. [CrossRef]

25. Lee, Y.-K.; Choi, J.; Moon, B.-Y.; Babin, B.J. Codes of ethics, corporate philanthropy, and employee responses. Int. J. Hosp. Manag. 2014, 39, 97-106. [CrossRef]

26. Marr, J.-A.; Sanders, G.; Neil, A.; Murphy, L. Creating a code of conduct to enable organizational change. Clin. Leadersh. Manag. Rev. 2006, 20, E5.

27. Von Der Embse, T.J.; Desai, M.S.; Desai, S. How well are corporate ethics codes and policies applied in the trenches? Key factors and conditions. Inf. Manag. Comput. Secur. 2004, 12, 146-153. [CrossRef]

28. Duppati, G.; Scrimgeour, F.; Stevenson, R. Corporate governance in the airline industry-Evidence from the Asia-Pacific Region. Corp. Ownersh. Control 2016, 13, 329-335.

29. Paek, S.; Chathoth, P.K. Multiple Levels of Ethics Management: A Case of Airline and Hotel Firms. Tour. Plan. Dev. 2013, 10, 388-415. [CrossRef]

30. Belyaeva, Z. CSR in the Russian aviation industry: The winds of change. Strateg. Dir. 2015, 31, 7-9. [CrossRef]

31. Cheng, Y.; Shen, H. United Airlines crisis from the stakeholder perspective: Exploring customers' ethical judgment, trust and distrust, and behavioral intentions. Public Relat. Rev. 2020, 46, 101908. [CrossRef]

32. Hagmann, C.; Semeijn, J.; Vellenga, D.B. Exploring the green image of airlines: Passenger perceptions and airline choice. J. Air Transp. Manag. 2015, 43, 37-45. [CrossRef]

33. Burns, P.M.; Cowlishaw, C. Climate change discourses: How UK airlines communicate their case to the public. J. Sustain. Tour. 2014, 22, 750-767. [CrossRef]

34. Top 100 Biggest Airlines by Number of Daily Departures. Available online: https://www.flightsfrom.com/ top-100-airlines (accessed on 28 July 2020).

35. Top Global Airlines in 2019, by Fleet Size. Available online: https://www.statista.com/statistics/1013159/ airlines-worldwide-fleet-size/ (accessed on 28 July 2020).

36. Kemp, S.; Dwyer, L. Mission statements of international airlines: A content analysis. Tour. Manag. 2003, 24, 635-653. [CrossRef]

37. Law, K.M.Y.; Breznik, K. What do airline mission statements reveal about value and strategy? J. Air Transp. Manag. 2018, 70, 36-44. [CrossRef]

38. Van der Waal, W.H.; Thijssens, T. Corporate involvement in Sustainable Development Goals: Exploring the territory. J. Clean. Prod. 2020, 252, 119625. [CrossRef]

39. Van Eck, C.; Milder, B.C.; van der Linden, S. Climate Change Risk Perceptions of Audiences in the Climate Change Blogosphere. Sustainability 2020, 12, 7990. [CrossRef]

40. Doliente, S.S.; Narayan, A.; Tapia, J.F.D.; Samsatli, N.J.; Zhao, Y.; Samsatli, S. Bio-aviation Fuel: A Comprehensive Review and Analysis of the Supply Chain Components. Front. Energy Res. 2020, 8, 10. [CrossRef]

41. Liu, S.; Zhu, Q.; Guan, Q.; He, L.; Li, W. Bio-aviation fuel production from hydroprocessing castor oil promoted by the nickel-based bifunctional catalysts. Bioresour. Technol. 2015, 183, 93-100. [CrossRef]

42. Saetbyeol, K. Analysis on ignition delay characteristics of bio aviation fuels manufactured by HEFA process. Korean Chem. Eng. Res. 2019, 57, 620-627.

43. Zhang, H.; Fang, Y.; Wang, M.; Deng, Y. Prospects and perspectives foster enhanced research on bio-aviation fuels. J. Environ. Manag. 2020, 274, 111214. [CrossRef] 
44. Nosachevskiy, K.; Nosachevskaya, E.; Afanasjeva, L. Implementation of National Projects in Russia: Approaches, Organization, Management Control. Vision 2025: Education Excellence and Management of Innovations through Sustainable Economic Competitive Advantage. In Proceedings of the 34th International-Business-Information-Management-Association (IBIMA) Conference, Madrid, Spain, 13-14 November 2019; pp. 150-155.

45. Semenova, G. Global environmental problems in Russia. E3s Web Conf. 2020, 157, 02023. [CrossRef]

Publisher's Note: MDPI stays neutral with regard to jurisdictional claims in published maps and institutional affiliations.

(C) 2020 by the authors. Licensee MDPI, Basel, Switzerland. This article is an open access article distributed under the terms and conditions of the Creative Commons Attribution (CC BY) license (http://creativecommons.org/licenses/by/4.0/). 